\title{
Research on Financing Constraints and Cost Stickiness in High Capacity Industries - From Empirical Tests of Steel Industry
}

\author{
Cailing $\mathrm{Xu}^{1, *}$ \\ ${ }^{1}$ Xinhua College of Sun Yat-sen University, Guangzhou, Guangdong 510520, China \\ *Corresponding author. Email: Cailingxuzhong@163.com
}

\begin{abstract}
Traditional cost model defines cost and business volume as mutually symmetric relationship. However, scholars, in the process of exploring the cost field proposed, that the range of cost change caused by business volume change is not completely symmetrical, and defined it as cost stickiness. Under financing constraints, enterprises will limit the adjustment cost, which will affect the cost stickiness. This paper selects China's steel listed companies from 2014 to 2018 as research samples. The research indicates that they have cost stickiness, and the cost stickiness of state-owned enterprises is stronger than that of non-state-owned enterprises; the stronger the financing constraints, the weaker the cost stickiness is. Moreover, compared with the central enterprises, the stickiness of provincial enterprises are more significant; when enterprises are under financing constraints, the cost stickiness of stateowned enterprises is more significant than that of non-state-owned enterprises, and that of provincial enterprises is more significant than that of central enterprises. The paper enriches the content of cost stickiness and is helpful for steel industry and other high capacity industries to effectively optimize the cost.
\end{abstract}

Keywords: high capacity industry, steel industry, cost stickiness, financing constraints

\section{INTRODUCTION}

The cost management and control of enterprises have gradually become an important means for enterprises to adjust their own development status. According to the traditional cost behavior model, there is a linear relationship between cost and business volume. The theory, put forward under ideal conditions, points out that the change range of cost and business volume is not related. Scholars at home and abroad have carried out in-depth research on the relationship between cost and business volume. Anderson (2003) and others proposed that the relationship between business volume and cost is not completely symmetric. When the business volume goes down, the cost reduction scope is smaller than that when the business volume goes up. Thus, there is cost stickiness. This theory impacts the traditional cost behavior theory and makes us have a deeper understanding of it.

Scholars' research on the model of enterprises' cost stickiness has an assumption that enterprises have enough funds as support in their operation. The research, carried out under this assumption, ignores the problem of capital shortage in real operation. The operation of enterprises must have enough working capital. However, China's capital market is not effective so enterprises are likely have capital shortage. The raising of funds will cause higher financing costs. That is, they will be subject to different degrees of constraints, called financing constraints.

Production capacity refers to the production capacity of an enterprise, the number of products that can be produced within a certain production condition and time. Due to the influence of various economic factors and the accelerated development of production technology, the production capacity of some industries has been expanded at a high speed. High capacity industries are cement, steel, flat glass, photovoltaic and coal. The production capacity of these industries expanded rapidly in high economic growth period but the demand did not increase at the same time, which resulted in overcapacity.

China's steel industry has made great achievements in the past 100 years, and gradually become mature, with the production capacity ranking first in the world, accounting for $36.4 \%$ of the total global steel production. The rapid expansion of production capacity has broken the balance between supply and demand, and lead to overcapacity and cost stickiness. When business volume increases, enterprises need to invest 
more in purchasing equipment to meet the capacity expansion. In the process of adjusting production resources, they will encounter financing constraints and the increase of the financing cost, which will affect the cost stickiness. On the other hand, when the business volume decreases, the equipment invested is idle. The retention of redundant resources will increase cost stickiness. When the financing constraints of enterprises are large, they should reduce the amount of redundant resources when business volume decreases in order to alleviate the financial difficulties. Thus, the cost stickiness will decrease accordingly.

Most of the researches on cost stickiness are about the verification of its existence and the comparison among different regions and industries. There are few considering the financing constraints of capital intensive industries in China. On this basis, the paper selects China's steel industry as the sample to explore the existence of cost stickiness and the impact of financing constraints on the cost stickiness of the steel industry. The research enriches the theoretical framework of cost stickiness and is helpful for steel enterprises to control their cost and for high capacity industries to better resolve their overcapacity.

\section{THEORETICAL ANALYSIS AND RESEARCH HYPOTHESIS}

\section{A. Existence of cost stickiness and its influencing factors}

Anderson (2003) and others proved the existence of cost stickiness and built ABJ model [1]. Subramaniam and weidenmier (2003) found that there was stickiness in the total cost of the sales and management expenses. They also pointed out that the change of sales revenue would affect the stickiness; when the proportion of sales revenue was greater than $10 \%$ compared with the lag period, stickiness would occur [2]. Liu Wu (2006) concluded that different industries had different stickiness levels. The stickiness level of the real estate industry was lower than such manufacturing industries as coal and steel, and information technology industries [3]. Li Yuhui (2018) proved that there was cost stickiness in China's steel industry, and verified the impact of internal and external environment to cost stickiness from the perspective of macroeconomic and operating income changes [4].

The total asset value of steel industry is large, and the transaction is generally based on long-term contracts, and the subsequent production and operation are bound to budgets. Therefore, the cost of adjusting production resources is also high. When the economy goes down, if the business volume decreases, the management will predict the adjustment cost considering the cost increase caused by business volume increases in the future. They are difficult to change the decision-making in a short time. In addition, the self-interest opportunism of managers makes them unwilling to take the initiative to rectify resources in order to maintain their own salary and company's image. The lacks of motivation for de-capacity and unreasonable allocation of resources will weaken its consequence. Jiang Feitao (2012) pointed out that, due to the influence of China's special government system, the promotion of officials takes GDP growth as one of the criteria. It leads to the self-interest motivation of local governments, the use of preferential measures to help enterprises, lower rent of industrial land and subsidies in financing loan to enterprises, which distorts market competition and eventually causes blind investment by local enterprises and unbalance of industry structure[5].Yang Zhen (2013) believed that the government's subsidies to state-owned enterprises, especially the loss making ones, will lead to the lack of motivation for enterprises with low production efficiency to exit the market and disrupt the normal market exit mechanism[6]. The property right structure of steel industry is different from that of foreign countries. Most of the enterprises are state-owned holding enterprises, deeply influenced by the will of the state. The government will maintain their operation by financial subsidies or taxes reduction. As a result, some steel enterprises are more dependent on national funds, lack of initiative, and virtually with over capacity. Enterprises with low production efficiency build barriers to prevent them from exiting market competition. On the contrary, without government support and help, non-state-owned enterprises have to be responsible for their own profits and losses, have more initiative than state-owned enterprises, focus on their own operational efficiency, and gain more profit by actively adjusting their capacity policy. Based on the above analysis, the first hypothesis is put forward:

Hypothesis 1: China's steel enterprises have cost stickiness and the cost stickiness of state-owned enterprises is stronger than that of non-state-owned enterprises.

\section{B. Financing constraints and cost stickiness}

Gertler (1994) proposed that when the business volume decreased, the enterprise will reduce the cost by reducing production because of the financing constraints [7]. Whited and Wu (2006) pointed out that in real operation, information communication between enterprises lagged behind, which would increase the financing cost and make enterprises suffer from the impact of financing constraints [8]. Weiss (2010) combined the profit and loss management and cost stickiness theory to prove that the production and operation of an enterprise would be affected by the adjustment cost. When a new business volume occurs, the enterprise needs to increase the corresponding labor force and equipment to expand production. This process 
requires financial support. Enterprises under financing constraints have higher external financing costs, which increases the adjustment cost in order to reduce the nonlinear range between cost and business volume, and weaken the cost stickiness of enterprises [9]. Liang Shangkun and Zhang Mengting (2015) found that when the tight monetary policy was implemented, the enterprise's operating enthusiasm under high financing constraints would reduce, and their own adjustment ability was weak, so they were more vulnerable to the intervention of tightening policy and to reduce cost stickiness. It verifies that the tight monetary policy will weaken the cost stickiness [10]. Jiang Wei, Hu Yuming and Zeng Yeqin (2015) found that the adjustment cost was restricted by financing constraints, which affected the cost stickiness. When the business volume increases, the enterprises under higher financing constraints will lead to nonlinear changes between the cost and the business volume, thus reducing the cost stickiness. When the business volume decreases, enterprises under high financing constraints will be affected. In order to avoid the financial crisis caused by the retention of redundant resources, the industry tends to reduce the redundant resources to weaken the cost stickiness [11]. Zhang Danwei (2017) used the cash sensitive model to classify the degree of corporate financing constraints, breaking the shackles of the ideal market theory and studying the impact of cost stickiness under different financing constraints [12]. Zhang Degang and Liu Yaona (2018), from the perspectives of the governance of the manufacturing listed companies, proved that when the degree of financing constraints was low, corporate management could effectively weaken the cost stickiness, or otherwise, the weaker the degree of stickiness reduction[13].

Information exchange is not timely in the capital market. When enterprises need funds because of the increase of business and expansion of production scale, they have to face higher financing costs, especially for asset intensive industries, such as steel enterprises, whose production level largely depends on fixed assets, inventory and other long-term investment. They cannot use more internal funds so they need external financing and are more vulnerable to the impact of financing constraints. In order to meet the increase of business volume, enterprises under strong financing constraints have to face higher financing costs, which increase the adjustment costs of enterprises. When the volume of business goes down, the redundant resources will be retained to reduce the current adjustment cost due to the difficulty of quick adjustment of production resources and the opportunism of management. However, enterprises with strong financing constraints will have greater financial risks and opportunity costs if retaining more excess resources

Enterprises may survive by disposing of surplus equipment to ease the short-term business crisis and thus weakens the cost stickiness. In conclusion, the second hypothesis is put forward.

Hypothesis 2: The stronger the financing constraints, the weaker the cost stickiness.

\section{RESEARCH DESIGN}

\section{A. Sample selection and data sources}

This paper takes the data of steel listed companies from 2013 to 2018 as the research object, and the data comes from Tong Hua Shun IFind database. Excluding the ST and *ST listed companies and the companies with incomplete financial data, 125 samples data are finally obtained. Using SPSS21.0 software, explores the influence of cost stickiness and its financing constraints in the steel industry.

\section{B. Research model and variable definition}

Based on the above-mentioned ABJ model of Anderson (2003), the paper builds model (1) to verify the hypothesis 1 :

$$
\begin{gathered}
\operatorname{Ln}\left(\frac{\operatorname{Cost}_{i, t}}{\operatorname{Cost}_{i, t-1}}\right)=\beta_{0}+\beta_{1} \operatorname{Ln}\left(\frac{\operatorname{Rev}_{i, t}}{\operatorname{Rev}_{i, t-1}}\right) \\
+\beta_{2} \operatorname{Dec}_{i, t} \operatorname{Ln}\left(\frac{\operatorname{Rev}_{i, t}}{\operatorname{Rev}_{i, t-1}}\right)+\varepsilon_{i, t}
\end{gathered}
$$

In model (1), Ln $\left(\operatorname{Cost}_{i, t} / \operatorname{Cost}_{i, t-1}\right)$ is the logarithm difference between the operating cost at the end of the current period and that at the end of the previous period, reflecting the change of operating cost. $L n$ $\left(\operatorname{Rev}_{i, t} / \operatorname{Rev}_{i, t-1}\right)$ is the logarithm of the current revenue minus the logarithm of the previous period's revenue, reflecting the change of business volume; $D_{e c} c_{i, t}$ is a dummy variable, set according to the change of current operating revenue. If the value of operating revenue minus the previous period's operating income is greater than 0 , then the dummy variable is 0 , otherwise it is 1 . $\beta_{0}$ is a constant term; $\varepsilon_{\mathrm{i} . \mathrm{t}}$ is an error term.If the operating revenue increases by one unit, the cost increases by $\beta_{1}$ units. If the operating income decreases, the cost decreases by $\beta_{1}+\beta_{2}$ units. According to the study of ABJ (2003) on cost stickiness, if $\beta_{1}>\beta_{1}+\beta_{2}$, listed companies in China's iron and steel industry are proved to have cost stickiness. It is inferred that if $\beta_{2}<0$, and $\beta_{1}$ $>0$, the smaller $\beta_{2}$, the greater the cost stickiness is.

The coefficient $\beta_{2}$ in model (1) determines the size of cost stickiness and the importance of other factors. Using Banker's methodology and, etc., the paper selects the main indicators affecting the cost stickiness to analyze $\beta_{2}$ and builds the regression model (2) as follows. 


$$
\begin{aligned}
\beta_{2}= & a_{0}+a_{1} \text { Growth }_{i, t}+\alpha_{2} \text { Liquid }_{i, t} \\
& +\alpha_{3} \times \text { Gross_profitit, }+\varpi_{i, t}
\end{aligned}
$$

Growth $_{i, t}$ is the growth rate of main business income, representing the growth vitality of the enterprise. When the business volume declines in the stable stage of an enterprise's operation, the adjustment of production capacity will be relatively slow; If the income increases continuously, the corresponding cost will also increase; Liquid $_{i, t}$ is the current ratio, representing the enterprise's repay ability with current assets, and reflecting its capital turnover rate and fundraising ability. The low turnover efficiency will accelerate the optimization and adjustment of production capacity, thus further reduce the cost stickiness; Gross_profit $t_{i, t}$ is the year-on-year growth rate of gross profit, reflecting the growth of gross profit and the change of enterprise profitability. If the profitability decreases, it will accelerate the optimization of industrial structure. $\omega_{i, t}$ is an error item.

Nowadays, there are several main measurement methods for financing constraints: cash flow sensitivity, financing constraint index and single characteristic variable. The paper calculates the $\mathrm{KZ}$ index according to the determined financial data by using the measurement methods of Kaplan and zingeles (1997), Zhang Tao and Guo Xiao (2018) and the index method [14]. The greater the financing constraints, the greater the index is. The calculation method of $\mathrm{KZ}$ index is as follows:

\section{$K Z=-1.001909 * O C F /$ Asset \\ $+3.139193^{*}$ Lev-39.3678*Dividends/Asset \\ $-1.314759 *$ Cash/Asset $+0.2826389 *$ Tobin's $Q$}

$O C F$ is net operating cash flow. Dividends is dividend payment rate, calculated by dividing dividend payable by net profit; Lev is asset liability ratio, calculated by dividing liabilities by total assets; Cash is the amount of cash held, indicated by balance of cash and cash equivalents; Asset is total assets; Tobin's $Q$ is Tobin $\mathrm{Q}$ value, indicated by market value $A$ divided by total assets.

Combining model (2) with model (1) and adding financing constraints, model (3) is built verify the hypothesis 2 as follows.

$$
\begin{aligned}
& \operatorname{Ln}\left(\frac{\text { Cost }_{i, t}}{\operatorname{Cost}_{i, t-1}}\right)=\beta_{0}+\beta_{1} \times \operatorname{Ln}\left(\frac{\operatorname{Rev}_{i, t}}{\operatorname{Rev}_{i, t-1}}\right) \\
& +\left(a_{0}+a_{1} \text { Growth }_{i, t}+\alpha_{2} \text { Liquid }_{i, t}+\alpha_{3} \times \text { Gross_profit }_{i, t}\right. \\
& \left.+\varpi_{i, t}\right) \operatorname{Dec}_{i, t} \times \operatorname{Ln}\left(\frac{\operatorname{Rev}_{i, t}}{\operatorname{Rev}_{i, t-1}}\right) \\
& +\alpha_{2} \times \text { Labor_Intensity }_{i, t} \times \operatorname{Dec}_{i, t} \times \operatorname{Ln}\left(\frac{\text { Rev }_{i, t}}{\text { Rev }_{i, t-1}}\right) \\
& +\beta_{3} K Z_{i, t} \operatorname{Dec}_{i, t} \operatorname{Ln}\left(\frac{\operatorname{Rev}_{i, t}}{\operatorname{Rev}_{i, t-1}}\right)+\varepsilon_{i, t}
\end{aligned}
$$

\begin{tabular}{|c|c|c|c|}
\hline Items & $\begin{array}{l}\text { Symbol of } \\
\text { Variable }\end{array}$ & Name of Variable & Definition of Variable \\
\hline $\begin{array}{l}\text { Dependent } \\
\text { Variable }\end{array}$ & $\begin{array}{l}\operatorname{Ln}\left(\operatorname{Cost}_{i, t}\right) \\
\left./ \operatorname{Cost}_{i,-1}\right)\end{array}$ & Cost change & $\begin{array}{l}\text { the difference between the natural logarithm of operating costs at the end } \\
\text { of the current period and that at the end of the previous period }\end{array}$ \\
\hline \multirow{2}{*}{$\begin{array}{l}\text { Independen } \\
t \text { Variable }\end{array}$} & \begin{tabular}{ll|}
$\operatorname{Ln}$ & $\left(\operatorname{Rev} v_{i, t}\right.$ \\
$\left./ \operatorname{Rev} v_{i, t-1}\right)$
\end{tabular} & \begin{tabular}{|l|l|}
$\begin{array}{l}\text { Changes in business } \\
\text { volume }\end{array}$ & \\
\end{tabular} & $\begin{array}{l}\text { the difference between the natural logarithm of the operating income at the } \\
\text { end of the current period and that at the end of the previous period }\end{array}$ \\
\hline & $K Z_{i, t}$ & \begin{tabular}{|l|}
$\begin{array}{l}\text { Degree of financing } \\
\text { constraints }\end{array}$ \\
\end{tabular} & the calculation method of $\mathrm{KZ}$ index shown above. \\
\hline \multirow{3}{*}{$\begin{array}{l}\text { Control } \\
\text { Variable }\end{array}$} & Growth $_{i, t}$ & $\begin{array}{l}\text { Growth rate of main } \\
\text { business income }\end{array}$ & growth of the company \\
\hline & Liquid $_{i, t}$ & Current ratio & current assets / current liabilities \\
\hline & Gross_profit $t_{i, t}$ & \begin{tabular}{|l|} 
Year on year growth \\
rate of gross profit rate,
\end{tabular} & $\begin{array}{l}\text { (gross profit of current year - gross profit of last year) / gross profit of last } \\
\text { year }\end{array}$ \\
\hline \multirow{2}{*}{$\begin{array}{l}\text { Control } \\
\text { Variable }\end{array}$} & Status $_{i, t}$ & Asset status & $\begin{array}{l}\text { the net value of fixed assets at the end of the current period divided by the } \\
\text { depreciation amount of the current year, and then take the natural } \\
\text { logarithm }\end{array}$ \\
\hline & $S O E_{i, t}$ & $\begin{array}{|ll|}\begin{array}{l}\text { Nature of property } \\
\text { rights }\end{array} & \\
\end{array}$ & 1 for state-owned enterprises, 0 for non-state-owned enterprises \\
\hline $\begin{array}{l}\text { Dummy } \\
\text { Variable }\end{array}$ & Deci,t & $\begin{array}{l}\text { The current business } \\
\text { volume decreased. }\end{array}$ & $\begin{array}{l}\text { When the main business income of the current period decreases, take } 1 \text {, } \\
\text { otherwise take } 0 \text {. }\end{array}$ \\
\hline
\end{tabular}

Based on model (3), regression test is done in SPSS21.0 software. The basic information of each variable in the above model is listed in "Table I".

TABLE I. VARIABLE DEFINITION 


\section{EMPIRICAL TEST}

\section{A. Descriptive statistics analysis}

Using SPSS 21.0 software, the descriptive statistics of related variables are shown in "Table II".

TABLE II. DESCRIPTIVE STATISTICS OF RELATED VARIABLES

\begin{tabular}{|c|c|c|c|c|c|}
\hline Variables & $\begin{array}{c}\text { Sample } \\
\text { Size }\end{array}$ & $\begin{array}{c}\text { Average } \\
\text { Value }\end{array}$ & $\begin{array}{l}\text { Standard } \\
\text { Deviation }\end{array}$ & $\begin{array}{c}\text { Maximum } \\
\text { Value }\end{array}$ & $\begin{array}{c}\text { Minimum } \\
\text { Value }\end{array}$ \\
\hline $\operatorname{Ln}\left(\operatorname{Cos}_{i, t} / \operatorname{Cost}_{i, t-1}\right)$ & 125 & 0.03 & 0.27 & 0.89 & -0.64 \\
\hline $\operatorname{Ln}\left(\operatorname{Rev}_{i, t} / \operatorname{Rev}_{i, t-1}\right)$ & 125 & 0.69 & 0.76 & 2.35 & -0.67 \\
\hline$K Z_{i, t}$ & 125 & 189.14 & 58.32 & 329.34 & 62.36 \\
\hline Growth $_{i, t}$ & 125 & 6.45 & 27.83 & 86.35 & -48.85 \\
\hline Liquid $_{i, t}$ & 125 & 0.94 & 0.66 & 3.69 & 0.14 \\
\hline Gross_profit ${ }_{i, t}$ & 125 & 77.23 & 287.29 & 2274.93 & -480.34 \\
\hline Status $_{i, t}$ & 125 & 0.77 & 0.24 & 1.46 & 0.04 \\
\hline$S O E_{i, t}$ & 125 & 0.80 & 0.40 & 1.00 & 0.00 \\
\hline Deci,t & 125 & 0.42 & 0.50 & 1.00 & 0.00 \\
\hline
\end{tabular}

The descriptive test results shows that the maximum value of $\operatorname{Ln}\left(\right.$ Cost $_{i, t} /$ Cost $\left._{i, t-1}\right)$ is 0.89 , the minimum value is -0.64 , the corresponding maximum and minimum value of $\operatorname{Ln}\left(\operatorname{Rev}_{i, t} / \operatorname{Rev}_{i, t-1}\right)$ are 2.35 and -0.67 respectively, indicating that the operating cost of the sample company in this year fluctuates greatly compared with that of the previous year.The average value of the variable $\operatorname{Ln}\left(\operatorname{Cost}_{i, t} / \operatorname{Cost}_{i, t-1}\right)$ and $\operatorname{Ln}\left(\operatorname{Rev}_{i, t}\right.$ $\left./ \operatorname{Rev}_{i, t-1}\right)$ is greater than 0 , indicating that the operating cost and operating income of the listed steel enterprises are gradually increasing, consistent with the actual situation. The average value of $K Z$ index is 189.14 , the maximum value 329.34 , and the minimum value 62.36 , indicating that there is a large gap in the degree of financing constraints of listed companies in the steel industry; the maximum value of variable The variable Growth $_{i, t}$, the growth rate of main business income is 86.35 , the minimum value is -48.85 , indicating that the fluctuation range of main business income of listed companies in steel industry is unstable and the profit and loss is unbalanced. Liquid $_{i, t}$ is 3.69 , and the minimum value is 0.14 , indicating that there is a large gap between the cash flow ability and turnover efficiency of enterprises. Gross_profit $t_{i, t}$, the maximum value 2274.93, and the minimum value -480.34 , indicates a large gap for their gross profit.

\section{B. Model regression analysis}

By using SPSS21.0 software, the paper verifies the existence of cost stickiness of the steel listed companies and its change level affected by financing constraints. The results are shown in "Table III", "Table IV" and "Table V".

TABLE III. REGRESSION RESULTS OF STICKINESS EXISTENCE WITH MODEL (1)

\begin{tabular}{|c|c|c|}
\hline \multirow[t]{4}{*}{ Variables/Items } & \multirow{2}{*}{\multicolumn{2}{|c|}{$\begin{array}{c}\operatorname{Ln}\left(\operatorname{Cost}_{\mathrm{i}, \mathrm{t}} / \operatorname{Cost}_{\mathrm{i}, \mathrm{t}-1}\right) \\
\text { Model (1) } \\
\end{array}$}} \\
\hline & & \\
\hline & \multicolumn{2}{|c|}{ Overall Data } \\
\hline & Index & P Value \\
\hline $\boldsymbol{\beta}_{0}$ & -0.192 & $.000 * * *$ \\
\hline$\beta_{1}$ & 0.323 & $.000 * * *$ \\
\hline$\beta_{2}$ & -0.250 & $.000 * * *$ \\
\hline Ln(Revi,t / Revi,t-1) & - & - \\
\hline$K Z i, t$ & - & - \\
\hline Growthi,t & - & - \\
\hline Liquidi,t & - & - \\
\hline Gross profiti,t & - & - \\
\hline F Statics & \multicolumn{2}{|c|}{147.481} \\
\hline Adjusted $R^{2}$ & \multicolumn{2}{|c|}{0.703} \\
\hline$N$ & \multicolumn{2}{|c|}{125} \\
\hline
\end{tabular}

Remarks: The level of ** is significant, and the level of * is significant at the level of $5 \%$.

TABLE IV. REGRESSION RESULTS OF STICKINESS EXISTENCE BETWEEN SOE AND NON-SOE WITH MODEL (1)

\begin{tabular}{|c|c|c|c|c|}
\hline \multirow[t]{4}{*}{ Variables/Item } & \multicolumn{4}{|c|}{$\operatorname{Ln}\left(\operatorname{Cost}_{\mathrm{i}, \mathrm{t}} / \operatorname{Cost}_{\mathrm{i}, \mathrm{t}-1}\right)$} \\
\hline & \multicolumn{4}{|c|}{ Model (1) } \\
\hline & \multicolumn{2}{|c|}{ SOE $_{i, t}=1$} & \multicolumn{2}{|c|}{$\operatorname{SOE}_{i, \mathrm{t}}=\mathbf{0}$} \\
\hline & Index & P Value & Index & P Value \\
\hline $\operatorname{Ln}(\operatorname{Revi}, t /$ Revi,t-1) & 0.202 & $.000 * * *$ & 0.022 & 354 \\
\hline Growthi,t & 0.004 & $.000^{* * * *}$ & 0.008 & $.000^{* * * *}$ \\
\hline Liquidi,t & -0.002 & .964 & -0.003 & 0.777 \\
\hline Gross profiti,t & 0.000 & $.000^{* * * *}$ & 0.000 & $0.054^{*}$ \\
\hline F Statics & \multicolumn{2}{|l|}{59.691} & \multicolumn{2}{|l|}{190.606} \\
\hline Adjusted $R^{2}$ & \multicolumn{2}{|l|}{0.748} & \multicolumn{2}{|l|}{0.975} \\
\hline$N$ & \multicolumn{2}{|l|}{100} & \multicolumn{2}{|l|}{25} \\
\hline
\end{tabular}


TABLE V. REGRESSION RESULTS OF STICKINESS UNDER FINANCING CONSTRAINTS WITH MODEL (3)

\begin{tabular}{|c|c|c|}
\hline \multirow[t]{3}{*}{ Variables/Item } & \multirow{2}{*}{\multicolumn{2}{|c|}{$\frac{\operatorname{Ln}\left(\operatorname{Cost}_{\mathrm{i}, \mathrm{t}} / \operatorname{Cost}_{\mathrm{i}, \mathrm{t}-\mathrm{1}}\right)}{\operatorname{Model}(3)}$}} \\
\hline & & \\
\hline & Index & P Value \\
\hline Ln(Revi,t/Revi,t-1) & 0.165 & $.000^{* * * *}$ \\
\hline$K Z i, t$ & -0.001 & $.026^{* *}$ \\
\hline Growthi,t & 0.005 & $.000^{* * *}$ \\
\hline Liquidi,t & -0.062 & $.032 * * *$ \\
\hline Gross profiti,t & 0.000 & $.000 * * *$ \\
\hline F Statics & \multicolumn{2}{|l|}{73.326} \\
\hline Adjusted $R^{2}$ & \multicolumn{2}{|l|}{0.778} \\
\hline$N$ & \multicolumn{2}{|l|}{125} \\
\hline
\end{tabular}

The results of "Table III" show that $\beta_{1}$ in model (1) is 0.323 , and $\beta_{2}$ is -0.250 , less than 0 . Thus, when the business income (or business volume) swings up by one unit, the operating cost increases by $0.323 \%$; when the business volume swings down by one unit, the operating cost decreases by $0.073 \%,\left(\beta_{1}+\beta_{2}\right)$, which indicates that China's steel industry has cost stickiness.

According to the results in "Table III", the $\mathrm{P}$ value of $\beta_{2}$ in model (1) is 0.00 , far less than $5 \%$, indicating that the significant difference between the change of cost and the change of business volume is obvious;and the change of business volume has a certain impact on the change of cost. The adjusted value of $R^{2}$ is 0.703 , indicating that the fitting degree between the linear fitting of the model and the original data is $70.3 \%$. Therefore, $70.3 \%$ of the operating cost changes can be determined and explained by the change of business volume involved in the study. The F value is 147.481, and the $\mathrm{P}$ value is 0.00 , consistent with the significance level of $1 \%$. From the above explanation, the regression results of model (1) are effective.

The enterprises in research are categorized by the state-owned and the non-state-owned. For the nature of property rights, except for Liquid ${ }_{i, t}$, the result in the "Table IV", the $\mathrm{P}$ value of other variables of stateowned enterprises is 0.00 , and the adjusted $\mathrm{R}^{2}$ is $74.8 \%$, indicating that the fitting degree is good. The $\mathrm{P}$ value of all variables in non-state-owned enterprises does not pass the $5 \%$ of significance level test, indicating that the significance of non-state-owned enterprises and cost changes are very small.

Therefore the cost stickiness of the state-owned enterprises is stronger than that of non-state-owned enterprises. State-owned enterprises have political connection with government, so they need to take the corresponding social responsibility and cannot adjust their production strategy in time. Thus, cost stickiness occurs. Non-state-owned enterprises will actively adjust excess capacity due to operational pressure, which makes cost stickiness not obvious. In conclusion, there is cost stickiness in China's steel industry; the cost stickiness of state-owned enterprises is more significant than that of non-state-owned enterprises. Hypothesis 1 is tenable.

Viewing "Table $\mathrm{V}$ ", the adjusted value of $\mathrm{R}^{2}$ in model (3) is $77.8 \%$, indicating that the linear regression model has good fitting degree, $\mathrm{F}$ value is 73.326 , and $\mathrm{P}$ value of each variable is less than $5 \%$. Therefore, the results of model (3) are proved effective.

The variable of $\mathrm{KZ}_{\mathrm{i}, \mathrm{t}}$ of financing constraints conforms to the significance level and further verifies $\mathrm{H} 2$. When enterprises' business volume goes up, they need to use external financing for the expanding production, which will lead to the increase of the corresponding production costs, and eventually form a nonlinear change between business costs and business volume. However, the stronger the financing constraints, the greater the financial risk is. Managers will reduce redundant resources for their own management needs, which make the cost stickiness weaker. Thus, hypothesis 2 holds.

\section{Further analysist}

"Table IV" has subdivided the nature of the property right in China's steel enterprises, which proves that state-owned enterprises have significant cost stickiness. Since China's steel industry includes central enterprises holding shares and provincial holding companies, different control levels will affect the strategy formulation and operation efficiency of enterprises, thus affecting the cost stickiness. Therefore, it is necessary to divide the control levels of enterprises. The test results are shown in "Table VI" and "Table VII".

TABLE VI. CONTROL LEVEL AND COST STICKINESS OF CENTAL ENTERPRISES

\begin{tabular}{|c|c|c|}
\hline \multirow[t]{2}{*}{$\begin{array}{l}\text { Variables/ } \\
\text { Items }\end{array}$} & \multicolumn{2}{|c|}{$\begin{array}{c}\text { Ln }\left(\operatorname{Cost}_{\mathrm{i}, \mathrm{t}} / \text { Cost }_{\mathrm{i}, \mathrm{t}-1}\right) \\
\text { Central Enterprises }\end{array}$} \\
\hline & Index & P Value \\
\hline $\operatorname{Ln}\left(\operatorname{Rev}_{i, t} / \operatorname{Rev}_{i, t-1}\right)$ & 0.028 & 0.519 \\
\hline Growth $_{i, t}$ & 0.009 & $.000 * * *$ \\
\hline Liquid $_{i, t}$ & 0.050 & 0.197 \\
\hline Gross profit $_{i, t}$ & 0.000 & 0.138 \\
\hline F Statics & \multicolumn{2}{|l|}{43.376} \\
\hline Adjusted $R^{2}$ & \multicolumn{2}{|l|}{0.880} \\
\hline$N$ & \multicolumn{2}{|l|}{30} \\
\hline
\end{tabular}


TABLE VII. CONTROL LEVEL AND COST STICKINESS OF PROVINCIAL ENTERPRISES

\begin{tabular}{|c|l|l|}
\hline \multirow{2}{*}{ Variables/Item } & \multicolumn{2}{|c|}{} \\
\cline { 2 - 3 } & \multicolumn{2}{|c|}{ Provincial Enterprises } \\
\cline { 2 - 3 } In(Revi, / Revi, $\boldsymbol{t}$-1) & 0.270 & \multicolumn{1}{|c|}{ P Value } \\
\hline Growthi, $\boldsymbol{t}$ & 0.002 & 0.163 \\
\hline Liquidi, $\boldsymbol{t}$ & 0.003 & 0.946 \\
\hline Gross profiti, $\boldsymbol{t}$ & 0.000 & $.000^{* * * *}$ \\
\hline $\boldsymbol{F}$ Statics & 46.669 \\
\hline Adjusted $\boldsymbol{R}^{\mathbf{2}}$ & 0.768 \\
\hline $\boldsymbol{N}$ & 70 \\
\hline
\end{tabular}

The change of business volume of the Central enterprises does not pass the significance test of $5 \%$. While the $\mathrm{P}$ value of provincial enterprises is 0.000 , and its significance level is $1 \%$. When the business volume of provincial enterprises increases by $1 \%$, the increase range of cost stickiness is $0.270 \%$. They obviously have cost stickiness. This is because the official promotion system based on GDP growth has little impact on the Central enterprises, and the provincial enterprises will be greatly affected by the interference of self-interest motivation of the local government. In order to maintain the status quo, some local governments will increase subsidies, tax incentives and key resources to local enterprises, which will hinder the enterprises from exiting the market and lead to greater cost stickiness. The Central enterprises are less affected by government intervention and their exit from the market will not be controlled by government resistance, so their cost stickiness is not significant.

The selected enterprises are further categorized according to the nature of property rights and control levels to study the change of cost stickiness with different property rights and control levels under financing constraints. The regression results are listed in "Table VIII" and "Table IX".

TABLE VIII. COST STICKINESS IN DIFFERENT PROPERTY RIGHT UNDER FINANCING CONSTRAINTS

\begin{tabular}{|c|c|c|c|c|}
\hline \multirow{3}{*}{$\begin{array}{c}\text { Variables/ } \\
\text { Items }\end{array}$} & \multicolumn{4}{|c|}{ Ln (Costi,t /Costi,t-1) } \\
\hline & \multicolumn{2}{|c|}{ State-owned Enterprises } & \multicolumn{2}{|c|}{$\begin{array}{c}\text { Non-state-owned } \\
\text { Enterprises }\end{array}$} \\
\hline & Index & P Value & Index & P Value \\
\hline $\operatorname{Ln}\left(\operatorname{Revi}_{i, t} / \operatorname{Rev}_{i, t-1}\right)$ & 0.186 & $.000 * * *$ & 0.021 & 0.388 \\
\hline$K Z_{i, t}$ & 0.004 & $.000 * * *$ & 0.008 & $.000 * * *$ \\
\hline Growth $_{i, t}$ & -0.001 & $.035 * *$ & 0.000 & 0.748 \\
\hline Liquid $_{i, t}$ & -0.082 & $.106 * * *$ & 0.001 & 0.964 \\
\hline Gross profit $_{i, t}$ & 0.000 & $.000 * * *$ & 0.000 & $0.058^{*}$ \\
\hline F Statics & \multicolumn{2}{|l|}{52.388} & \multicolumn{2}{|l|}{151.383} \\
\hline Adjusted $R^{2}$ & \multicolumn{2}{|l|}{0.757} & \multicolumn{2}{|l|}{0.974} \\
\hline$N$ & \multicolumn{2}{|l|}{100} & \multicolumn{2}{|l|}{25} \\
\hline
\end{tabular}

TABLE IX. COST STICKINESS IN CONTROL LEVELT UNDER FINANCING CONSTRAINTS

\begin{tabular}{|c|c|c|c|c|}
\hline \multirow{3}{*}{$\begin{array}{l}\text { Variables/ } \\
\text { Items }\end{array}$} & \multicolumn{4}{|c|}{ Ln (Costi,t /Costi,t-1) } \\
\hline & \multicolumn{2}{|c|}{ Central Enterprises } & \multicolumn{2}{|c|}{ Provincial Enterprises } \\
\hline & Index & PValue & Index & PValue \\
\hline $\operatorname{Ln}\left(\operatorname{Revi,t} / \operatorname{Rev}_{i, t-1}\right)$ & 0.029 & 0.463 & 0.273 & $.000 * * *$ \\
\hline$K Z_{i, t}$ & 0.009 & $.000 * * *$ & 0.001 & 0.193 \\
\hline Growth $_{i, t}$ & -0.001 & $.021 * *$ & 0.000 & 0.850 \\
\hline Liquid $_{i, t}$ & -0.087 & 0.195 & 0.015 & 0.847 \\
\hline Gross profit $_{i, t}$ & 0.000 & $.038 * *$ & 0.000 & $.000 * * *$ \\
\hline F Statics & \multicolumn{2}{|l|}{44.974} & \multicolumn{2}{|l|}{38.311} \\
\hline Adjusted $R^{2}$ & \multicolumn{2}{|l|}{0.901} & \multicolumn{2}{|l|}{0.764} \\
\hline$N$ & \multicolumn{2}{|l|}{30} & \multicolumn{2}{|l|}{70} \\
\hline
\end{tabular}

Combining "Table IV" and "Table VIII" adding variables of financing constraints, when the business volume coefficient of state-owned enterprises decreases by $0.016(0.202-0.186)$,their cost stickiness under financing constraints is more significant than that of non-state-owned enterprises. This is because the stateowned enterprises have more financing advantages than non-state-owned enterprises, and the financing constraints are smaller. The state-owned banks are the creditors with the highest proportion in the creditor's rights structure of state-owned enterprises. The government plays the role of guarantor for the stateowned enterprises behind, which reduces the financing risk of state-owned enterprises and provides enough fund for their expansion of production capacity. As a result, the enthusiasm of state-owned enterprises to adjust the production structure is insufficient and the cost stickiness is strong.

On the other hand, the cost stickiness of provincial enterprises are more significant than that of the Central enterprises under financing constraints. With the 
support of the government, local provincial enterprises get more preferential financing than the Central enterprises. They have more ways to obtain funds and have lower capital cost. The financing constraints are relatively small, and it is likely to over invest, which leads to the decrease of motivation for local provincial enterprises to optimize the cost mechanism, and the cost stickiness is obvious.

\section{Robustness test}

Based on the above empirical regression analysis, the asset status is used as an independent variable and SPSS21.0 is used for linear regression. The regression analysis results are shown in "Table X".

TABLE $X . \quad$ TABLE OF ROBUSTNESS TEST

\begin{tabular}{|c|l|l|l|}
\hline Variables & \multicolumn{1}{|c|}{ Index } & P Value & Durbin-Watson \\
\left.\hline${\left.\text { Ln( } \boldsymbol{R e v}_{i, t} / \boldsymbol{R e v}_{i, t-1}\right)}\right)$ & 0.165 & $.000^{* * *}$ & 1.968 \\
\hline Status $_{i, t}$ & 0.140 & $.005^{* * *}$ & 1.968 \\
\hline $\boldsymbol{F}$ Statics & 73.326 & \\
\hline Adjusted $\boldsymbol{R}^{2}$ & 0.778 & \\
\hline $\boldsymbol{N}$ & 125 & \multicolumn{3}{|l}{} \\
\hline
\end{tabular}

The adjusted $R^{2}$ is 0.778 , indicating that the fitting degree of the linear model is high. The $\mathrm{D}-\mathrm{W}$ value is 1.968 , indicating that there is no sequence correlation between the data. Therefore, the test results are proved effective. The coefficient of the variable status $s_{i, t}$ is 0.140 and passes the test of $1 \%$ significant, indicating that the factor is conducive to reduce the cost stickiness. When the value of asset status increases, the cost stickiness will become lower. In conclusion, the influence of asset status on the cost stickiness of listed companies in China's steel industry has not changed. The regression results of the paper are robust.

\section{CONCLUSIONS AND SUGgESTIONS}

\section{A. Conclusions}

Taking steel listed companies as examples, the paper studies the existence of cost stickiness and its change under financing constraints. It has the following conclusions:

- The steel listed companies have cost stickiness, and its level is $25 \%$. When business volume swings up and down by one unit, the difference of corresponding operating cost increases or decrease by 0.25 . The state-owned enterprises have stronger cost stickiness than non-stateowned enterprises.

- The stronger the financing constraints, the weaker the cost stickiness is.

- Provincial enterprises have more significant cost stickiness than the Central enterprises, due to the influence of local governments. Under financing constraints, state-owned enterprises have more significant cost stickiness than non-state-owned ones; and provincial enterprises more significant than the Central ones.

\section{B. Suggestions}

In order to help steel industry to better control their cost and cost stickiness, the following suggestions are given:

- The government should strengthen the supervision of managers, reduce the cost stickiness caused by managers' motivation, stimulate enterprise managers' motivation, play a positive role in the market, and improve the accounting supervision system and strictly control the cost management of listed companies. Enterprises should reasonably allocate resources, make optimal cost and operation strategies, effectively control costs and expenses, optimize production capacity structure, predict market trends in advance, fully understand the periodicity of the steel market, reasonably control capacity investment, try to avoid the increase of adjustment costs caused by economic cycle, improve business efficiency and investment return. The government should balance the market position of state-owned enterprises and non-state-owned enterprises, reduce the first-aid subsidies to state-owned enterprises and reduce their dependence on state funds, and force declining enterprises to actively adjust their production strategies and weaken their cost stickiness.

- In daily operation, enterprises should clarify the logical relationship between financing constraints and cost control, retain reasonable financing constraints so as to effectively avoid the waste of costs and unreasonable resource allocation. Financing constraints should positively impact cost control and further reduce the cost stickiness of enterprises.

- Local governments should give more operational autonomy to local provincial 
enterprises, give full play to the market competitive advantage of the survival of the fittest, and pay more attention to the production and operation efficiency. The government should reduce the preferential financing for state-owned enterprises, especially provincial enterprises, and encourage them to actively make optimal financing operation strategies, actively participate in market competition and maintain a reasonable production capacity structure.

\section{References}

[1] Anderson, M., Banker, R., Janakiraman S. Are Selling, Genera,and Administrative Costs "Sticky"?[J].The Accounting Review,2003.

[2] Chandra Subramaniam,Marcia L. Weidenmier, Additional Evidence on the Sticky Behaviour of Costs[J].Working Paper,2003: 45-47

[3] Liu Wu. Firm Cost Stickiness: An Empirical Study Based on industry differences $[\mathrm{J}]$. China industrial economy, 2006 (12): $105-112$

[4] Li Yuhui. Empirical Study on Cost Stickiness of China's Steel Industry [J]. Accounting Learning, 2018, 01:94-95

[5] Jiang feitao, Geng Qiang, LV Daduo, Li Xiaoping. Formation Mechanism of Regional Competition, System Distortion and Overcapacity [J]. China Industrial Economy, 2012 (06): 44-56

[6] Yang Zhen. Research on the Formation Mechanism and Governance of Overcapacity from the Perspective of Incentive Distortion[J]. Economist, 2013 (10): 48-54

[7] M. Gertler, S. Gilchrist. Monetary policy, business cycles and the behavior of small manufacturing firms[J].The Quarterly Journal of Economics, 1994, 109(2):309-340.

[8] Whited, T.M. and Wu, G. (2006) Financial Constraint Risk[J]. The Review of Finance Studies, 19,:531-559.

[9] Weiss,D.Cost Behavior and Analysts' Earnings Forecasts[J].The Accounting Review, 2010(4): 1441-1471.

[10] Liang Shangkun, Zhang Mengting. Monetary Policy, Financing Constraints and Corporate Cost Stickiness[J]. Finance Quarterly, 2015,9 (02): 26-60

[11] Jiang Wei, Hu Yuming, LV Zhe. Does Accrual Earnings Management Affect the Cost Stickiness of Enterprises[J]. Nankai Management Review, 2015,18 (02): 83-91

[12] Zhang Danwei. Liquidity Management, Financing Constraints and Enterprise Cost Stickiness: An Empirical Analysis Based on Listed Manufacturing Companies in China[J]. China Business Theory, 2017 (03): 95-97

[13] Zhang Degang, Liu yaona. Financing Constraints, Corporate Governance and Cost Stickiness[J]. Accounting Communication, 2018 (21): 100-105

[14] Zhang Tao, Guo Xiao. Research on Executive Compensation Contract and Financing Constraints - Based on Empirical Data of A-share Listed Companies in Shanghai and Shenzhen[J].Economic and Management Review, 2018,34 (01): 96-107 